\title{
Re-Establishing Human-Nature Relations: Responses of Indigenous People of Indonesia to Covid-19
}

\author{
Samsul Maarif \\ Lecturer, Magister in Religious and Cross-cultural Studies, Graduate School, \\ Universitas Gadjah Mada, Yogyakarta, Indonesia \\ samsul.maarif75@ugm.ac.id
}

\begin{abstract}
Indigenous peoples of the world, including those of Indonesia, were more potentially at risk for Covid-19, due to their being marginalized and thus their lack of access to necessary information resources. Despite being marginalized and vulnerably impacted by the pandemic, indigenous people of Indonesia had re-contextualized their indigenous strategies that enabled them to survive and even offer lessons worth considering: indigenous ecocentrism. Data on their ideas and responses to the pandemic were collected through weekly webinars, featuring representatives of indigenous people as the main speakers, personal calls, and supported by a series of fieldwork, including data on the situation before the pandemic. Their responses to the pandemic were commonly based on ecocentrism; that Covid-19 was an ecological disaster caused by human's misconducts against humanity and human-nature relations. In response, they took responsibilities to perform eco-centric rituals, and called for a re-establishment of ecological human-nature relations to deal with Covid-19.
\end{abstract}

\section{Keywords}

indigenous people - Covid-19 - ecocentrism - Indonesia

\section{$1 \quad$ Background}

Soon into the pandemic, the Indonesian government announced a national emergency due to Covid-19 on 2 March 2020; and especially those who were 
working with indigenous peoples were extremely concerned. They were worried as it would have been unimaginable were Covid-19 to reach indigenous peoples. Not only were they well-informed that the indigenous peoples of the world were potentially more at risk of being infected by Covid-19 - due to their being marginalized and thus having a lack of access to necessary resources, ${ }^{1}$ but they had also witnessed that most indigenous people of Indonesia were still struggling to obtain state recognition along with their civil and political rights, as well as economic and cultural rights. Some of them had not yet accessed their legal status and were in ongoing conflicts with both corporations and local governments over their indigenous lands, let alone access to proper healthcare. Healthcare facilities were mostly inadequate in areas where indigenous people lived. Like other indigenous peoples around the world, those of Indonesia were very vulnerable.

In responses, two nationally based organizations, Aliansi Masyarakat Adat Nusantara (AMAN, the Alliance of Indigenous People of the Archipelago) ${ }^{2}$ and Majelis Luhur Kepercayaan Indonesia (MLKI, the Council for Indigenous Religions of Indonesia $)^{3}$ consolidated their members. Either of them had different members of communities, but some overlapped, being members of both

1 Sepkowitz, The Risk to Native American nations; Indigenous Services Canada, Addressing Urgent; Vieira et al., COVID-19: The Forgotten.

2 AMAN established in 1999 was a national NGO whose members were more than two thousand indigenous communities all over the archipelago, with approximately 17 million individuals (see Aliansi Masyarakat Adat Nusantara, Homepage). Those members were mostly in villages or remote areas. The organization was to advocate the rights of indigenous peoples especially over their (indigenous) lands/forests. AMAN was to reclaim their constitutional rights as indigenous communities, especially their rights over lands, completely negated during the New Order (1966-1998). After the Reformation (1998), AMAN and its alliances had made some progress through their advocacies for the state's recognition of indigenous peoples' rights. Kasmito Widodo, the director of Badan Registrasi Wilayah Adat (BRWA, the registering body of indigenous territories), AMAN's alliance working for the rights of indigenous peoples, reported in an online seminar that per August 2020, BRWA had registered 865 indigenous territories covering 11.116.45o hectares of indigenous lands. 1,5 millions hectares had been regulated (recognized) by local governments (mandated by the state's regulations requiring local regulations for recognition by the central government), but only 44.630 hectares had been recognized by the central government, the Ministry of Environment and Forestry per August 2020. Widodo, Dampak Hilangnya Wilayah Adat.

3 Kepercayaan, which literally meant belief, was the legal term for indigenous religions (see Majelis Luhur Kepercayaan: Peraturan \& Perundangan). MLKI was declared in 2014 as a new name of a council for groups of indigenous religions. The organization, which was firstly established in the early years of the Indonesian independence, had changed its name four times: BKKI, ВКОК and HPK. MLKI, working closely with the Directorate of Kepercayaan and Masyarakat Adat, General Directorate of Culture, the Ministry of Education and Culture, had 190 members of Kepercayaan groups, with approximately 12 million individuals. More groups 
organizations. It was not easy for them to consolidate their members because the internet as the main medium of communication during the Pandemic was not accessible to most of their members.

From the beginning of the Pandemic, AMAN established a national task force to deal with Covid-19. In early April 2020, the task force provided a guideline for dealing with Covid-19 for village heads in indigenous communities. The guideline explained strategies of dealing with Covid-19, from the legal way of rearranging and using village budgets, forming village-based Covid-19 task forces, to creating legal actions of lockdown. In addition, AMAN organized a series of radio talk shows with representatives of indigenous communities. The series discussed several themes and issues pertaining to Covid-19, including the update of their situations. Among the issues included, their various strategies in dealing with Covid-19 shall be elaborated in following sections.

MLKI in turn issued a letter to all members, instructing them to follow the governments' policies with regard to Covid-19 such as social distancing, wearing masks, working from home, and so on. Working with the Directorate of Kepercayaan and Masyarakat Adat, a specific state directorate under the Ministry of Education of Culture, the Indonesia Republic, MLKI organized trainings and capacity building series for its members, such as internet skills, especially for their school children. In addition, a coalition of 10 civil society organizations (CSO), including MLKI, established in 2019 following up a collaborative project supported by USAID through Peduli program, the Oslo Coalition on Freedom of Religion or Belief, University of Sydney for the First International Conference on Indigenous Religions which involved academics, activists and indigenous communities' members of Indonesia and beyond, organized weekly webinars (from May to November 2020). In each webinar, they involved 2 to 4 speakers of kepercayaan and 1 discussant of relevant experts coming from academicians, activists, or policy makers. The weekly webinars discussed various themes and issues, including updates of MLKI members' situations dealing with the Covid-19 pandemic.

In December 202O, the ninth month of the pandemic, the two organizations reported none of their members positive or infected by Covid-19. Some of their members informed in webinars that they had even been involved in community services helping those of their fellow citizens: the non-indigenous peoples or non-followers of indigenous religions infected by Covid-19.

Based on data collected from a series of radio talk shows by AMAN, the weekly webinars of the coalition, other webinars on indigenous religions/

were expected to register to it. Most of their members were in Java and cities. In contrast to AMAN, MLKI focused on the state's recognition of their indigenous religion (kepercayaan). 
peoples during the pandemic organized by several parties which were all publicly accessible through internet (mainly YouTube), and personal interviews with relevant individuals of indigenous people, this paper argues that despite of being marginalized and thus vulnerably threatened by the pandemic, the indigenous peoples of Indonesia had re-contextualized their indigenous strategies that enabled them to survive, adopting internet as their media for getting involved in public sphere, and even offering universal lessons worth considering what scholars called "the ecocentric paradigm."

To begin with, this paper examines citizenship status of followers of kepercayaan that have been discriminated against due to the state's governance on religious affairs through which indigenous religions were not recognized until as recently as 2017. As consequences, indigenous peoples were politically discriminated against and socially excluded, and could not access their citizenship rights. After the policy of recognition in 2017, there had been some improvements in the state's services and social inclusion for indigenous peoples, but many were still to pursue. Their situations were still on the margin, especially during the pandemic.

\section{The Citizenship of Indigenous People}

Since its independence, Indonesia has used agama (religion) to index the citizens. Agama was even one of the indexes to serve in order to qualify for Indonesian citizenship. Inheriting the Dutch colonial way of defining and governing religions (agama), the Indonesian government initially had come to identify three agama to serve and protect: Islam, Protestantism and Catholicism until in 1962, Hinduism and Buddhism were added, and Confucianism in 2001. Those six agama were all imported "world religions", and no agama of indigenous peoples was recognized.

The Indonesian government did not have a hard time to come up with a discriminating definition of agama to recognize the imported "world religions", ignoring and even outlawing indigenous religions. The European invention of "world religions" in the 19th century ${ }^{5}$ was a ready package for universal application. The way religion was reified in Europe and the West in general ${ }^{6}$

4 Gladwin/Kennelly/Krause, Shifting Paradigms for Sustainable Development; Gray/Whyte/ Curry, Ecocentrism; Taylor/Chapron/Kopnina/Orlikowska/Gray/Piccolo, The need for ecocentrism.

5 Masuzawa, The Invention of World Religions.

6 Smith, The Meaning and End of Religion; Smith, Map is not Territory; Smith, Religion, Religions, Religious. 
was appropriated in Indonesia. ${ }^{7}$ The appropriation was first introduced by the Dutch colonial through its policy of separating Islam (agama) from adat categorized as tradition, custom or culture in the beginning of the 2oth century as its divide et impera strategy of pressuring the militant Muslims and allying with adat groups. Adopting the western construction of religion, the Dutch colonial treated Islam and adat differently: Islam was treated as agama whose followers were guaranteed the freedom to practice their agama for piety but restricted to engage in political movement, whereas adat was treated as tradition or custom. It was primitive, and so in need for development and modernization. ${ }^{8}$ The colonial divide et impera resulted in not only separating Islam from adat, but also constructing adat as non-religious (not agama). ${ }^{9}$ The Dutch colonial appropriation was strengthened by the post-colonial government of Indonesia. The difference was that in Europe or the West the concept of religion was Christian-minded, ${ }^{10}$ and in Indonesia agama was defined especially by the post-colonial government to privilege Islam. ${ }^{11}$ The five religions mentioned above must conform to Islam, satisfying the Islamic characteristics, in order to qualify for recognition, ${ }^{12}$ and adat whose dimensions included religious practices was misrecognized as non-religious, following the western construction of animism, primitivism, magic, totemism, and so forth to justify for modernization, development, and also conversion (to recognized religions). ${ }^{13}$

Based on the appropriation, no religion born in Indonesia was recognized. In the Indonesian constitution, the word kepercayaan (literally means belief) was actually mentioned after agama. Article 29 stated "The State guarantees all persons the freedom of worship, each according to his/her own religion or belief." 14 The word "belief" was, however, interpreted as no separate entity, but part of agama. According to the official and dominant interpretation, adat and kepercayaan were not satisfying the required criteria of being agama. Groups of kepercayaan/adat had struggled for state recognition equal to those "world religions" since the independence (1945), but were misrecognized until 2017. Following up the 1965 tragedy of mass killing, ${ }^{15}$ the authoritarian New Order

7 Picard/Madinier, Politics of Religion; Maarif, Pasang Surut Rekognisi.

8 Maarif, Dimensions of Religious Practice.

9 Tuhri, Adat, Land, and Religion.

10 Owen, The World Religions paradigm; Cox, From Primitive to Indigenous; Bell, Paradigms behind (And before); Masuzawa, The Invention of World Religion; Dubuisson, The Western Construction of Religion.

11 Maarif, Pasang Surut Rekognisi; Maarif, Meninjau Ulang Definisi Agama.

12 Picard/Madinier, Politics of Religion; Maarif, Pasang Surut Rekognisi.

13 Maarif, Dimensions of Religious Practice; Tuhri, Adat, Land, and Religion.

14 Refworld, Constitution of the Republic of Indonesia.

15 Robinson, The Killing Season. 
regime (1996-1998) used agama as a counter ideology against communism to sweep the communist party members, sympathizers and accused affiliates. Many groups of kepercayaan/adat were victims, accused of being communist sympathizers or affiliates, and in order to escape from the sweeping, they had to convert or affiliate to one of the recognized religions.

In the early 1970s, the situation was considered to be conducive for groups of kepercayaan to advocate their rights for recognition. Although kepercayaan was not admitted as agama, the New Order government guaranteed public services to the followers from 1973 to 1978 . The same regime, however, changed its policy with regard to kepercayaan in 1978 as a result of its political bargains of imposing Pancasila, the Indonesia state philosophy, as a sole ideological principle to any social and political organization, including the Islam based political party. ${ }^{16}$ Based on a parliamentary resolution in 1978, Pancasil as the sole ideological principle was accepted and successfully imposed afterword, and kepercayaan was stated as not agama. but budaya (culture), and the followers were obliged to have an agama (converting to one of the five recognized) in order to access the state's public services. ${ }^{17}$ Enforcing the policy, the New Order government included a column of agama in citizenship ID cards. Since then, the followers of kepercayaan had no choice but showing their affiliation to one of the recognized agama in order for them to access basic needs of citizenship such as birth certificates, marriage certificates, healthcare, civil service jobs, and education. In schools in which agama was a required subject, school children of kepercayaan had to study agama. It was a common narrative among kepercayaan followers and those who worked with them that the agama education was the most effective means of the state to cleanse their generation. Some described this fact as a kind of cultural genocide.

The policy did not change until 2006. Based on two articles of the Indonesian law on Civic Administration 23/2006, followers of kepercayaan may leave the column of agama in their ID cards blank. They no longer had to put an agama, but at the same time were not allowed to put kepercayaan in their ID cards. It was already a breakthrough policy freeing them from being forced to choose an agama, but their citizenship rights were not yet fully recognized and fulfilled. As a matter of fact, they were subject to stigmas and even accusations of having no religion, becoming communist or anti-religion. Such stigmas had become social norms to socially exclude kepercayaan followers, and even become legal norms that justified the state officials' discrimination against them or their refusal to serving them. For such reasons, accompanied by

16 Ismail, Pancasila as the Sole Basis.

17 Maarif, Pasang Surut Rekognisi. 
several nationally and locally based civil society organization (Cso) activists who advocated groups of kepercayaan for several years, representatives of the groups petitioned the two discriminative articles to the Constitutional Court of Indonesian Republic in 2016. It took more than a year that the Constitutional Court finally approved the petition. The Constitutional Court announced its decision on 7 November 2017 allowing the followers to put their kepercayaan in their ID cards. The decision was publicly controversial, but was admitted as legally final and binding and so the kepercayaan citizenship status was eventually constitutionally granted.

It is worth noting that the above petition resulting in approval by the Constitutional Court was a significant part of a strategic advocacy of social inclusion by csos. The petition was one of follow-up advocacy interventions for the empowerment of kepercayaan groups and social acceptance of kepercayaan by the wider society and public services. ${ }^{18}$ Following up the decision, there had been significant improvements in the state's services and social inclusion for followers of kepercayaan. The kepercayaan followers may have their kepercayaan in their ID cards, choose their own kepercayaan education, and register their kepercayaan marriages. However, in several institutions, including the police and military, they still experienced various kinds of discriminations. In June 2020, MLKI reported that one of its members was rejected by the military institution of West Kalimantan because of his kepercayaan. They shared stories that their kepercayaan was still questioned in offices of public services such as in hospitals.

Despite the Constitutional Court Decision, political attempts excluding or even criminalizing followers of kepercayaan were still rampant. Indonesia's draft of a criminal code, which was still in the process of being adopted by the People's Representative Council (DPR), included blasphemy laws (on religion). A coalition of human rights defenders had protested through a series of seminars and drafted a policy brief against the bill, especially on the section of the blasphemy laws. The draft (of the blasphemy laws), according to the coalition, was a serious threat for followers of kepercayaan because it implicitly stated to protect the recognized religions from defamation. One of the articles stated that persuading people to disassociate with religion (agama) was criminal. This article was understood as threatening followers of kepercayaan, many of whom were still in the process of changing their ID cards from having agama to having kepercayaan. If passed as it was, the bill would carry on the dark history of kepercayaan in the New Order. It is argued that drafters of the bill

18 Maarif/Mubarok/Sahroni/Roessusita, Merangkul Penghayat Kepercayaan. 
ignored a series of discriminations against followers of kepercayaan and legal arguments of the Constitutional Court Decision.

In addition, most concerning for followers of kepercayaan and their sympathizers was social exclusion. Kepercayaan followers, as shared in webinars, still received negative stigmas for their kepercayaan as being irreligious or primitive in their social interactions, even from their neighbors. The Constitutional Court Decision was not yet widely socialized or socially accepted. Their right to have kepercayaan education in schools was still ignored. Social exclusion was regarded necessary to be addressed by advocacy agendas.

When the Pandemic hit Indonesia and was followed by the government's social distancing and lockdown policy, the internet became the most effective media of communication. Soon after those policies became effective, zoom seminars started to boom. Working from home (WFH) became popular. The people, including indigenous people, had to engage with the internet. It was initially not easy for MLKI to run their programs, which were mainly on capacity building for their members. There was no other solution apart from engaging with the internet. Just like other groups of Indonesia, MLKI members adjusted to the internet, learned how to use media that could facilitate their communication and consolidation, up to the point where their members could hold their congregation online as well as various trainings (for capacity building), including online seminars.

As already mentioned, a coalition by MLKI and Puan Hayati (women association for indigenous religions), which was established in 2019, organized the Forum Kamisan Daring (FKD, the online Thursday Forum) from May to November 2020. It was a weekly online seminar, taking place every Thursday night from 7:30-10 PM. It facilitated representatives of kepercayaan to act as the main speakers (two to four of them), and a discussant with relevant expertise - such as academicians, researchers, activists, and governmental officials. Attendees of FKD were from 40-9o in number every week. They were from diverse backgrounds: members of MLKI, students, academicians, activists, practitioners, and so forth. The $\mathrm{FKD}$, and several series of online seminars on indigenous religions organized by various organizations, were perceived as effective media of socialization between indigenous religions and the public.

Kepercayaan followers even expressed their thankfulness about the specific situation (ability to organize intensive and effective consolidation) during the Pandemic. Despite its various serious problems that everyone needed to deal with, the Pandemic had offered opportunities for followers of indigenous religions to speak in (online) public, express themselves freely, and share their opinions on various public issues. Some representatives of Kepercayaan conveyed their thankfulness for having the opportunity to speak in public. 
It was their first time to do so. It was something special for them, because their experiences as being an indigenous religion follower were mostly about social exclusion. Their religions were, as far as they could remember, stigmatized as heretical, irrational, primitive or even irreligious.

It is a common narrative among indigenous religion followers of Indonesia that every occurrence is existentially cosmic, ${ }^{19}$ and so there are always values to grasp and transform. ${ }^{20}$ For them, the Pandemic, despite the disasters it brought, offered lessons to learn from and thus needed to be wisely accounted for. The indigenous people under research seemed to share some ideas in common with the indigenous scholar and mixed-blood American, Don T. Jacobs who has advocated fearless movement, known as Four Arrows, since 197os. R. Michael Fischer \& Four Arrows promoted a fearlessness paradigm over a fear paradigm approach in response to scaremongering on Covid-19. They proposed to even consider Covid-19 as a gift for encouragement to move from biophobia to biophilia. They promoted inner self-awareness with the statement "I am not afraid to die", and proposed critical questions as a challenge to scaremongering on Covid-19: "What is it that is allowing us to focus on this [CoviD-19] with such passion all over the world?"21 For them, it was because of the fear paradigm that people dissociated from or destroyed the very source of life, which included the reality of death. ${ }^{22}$ They both argued, however, that the existence of Covid-19 should not be denied or escaped from, but admitted that at the same time there was too much scaremongering, a massive hypnosis, people creating and attacking scapegoats, and thus it would be nothing but a war of wars. ${ }^{23}$

In comparison with Fischer \& Four Arrows, all representatives of indigenous peoples, invited to speak at the online seminars, commonly narrated that the pandemic was not foreign to them. Each community had their own local terms of diseases associated with Covid-19. They accepted its existence and real threats, and so did their best and were willing to cooperate with any parties, especially with the government to anticipate and deal with it. For them,

19 Jehanu et al., Kepercayaan and Pandemi; Maarif, Indigenous Religion Paradigm.

20 ICIR, Homepage.

21 Fischer/Four Arrows, Pandemic, Fearless, and an Indigenous Perspective, p. 77.

22 Fischer/Four Arrows, Pandemic, Fearless, and an Indigenous Perspective, p. 77.

23 Fischer/Four Arrows, Pandemic, Fearless, and an Indigenous Perspective, p. 79. 
Covid-19 was nothing but another kind of disease. It was unique, but its causes were understandable, consequences were predictable, and the way to deal with it was comprehensible in their indigenous logic.

The representatives of kepercayaan groups explained the Covid-19 in their own terms. They were fearless, not panicking, and even certain about their own ways of dealing with it. They explained what they ought and should do, but were also honest that there was no guarantee to be $100 \%$ free from the Covid-19 threat. If infected or even killed by it, they would have to carry the consequences. Those consequences, in their opinion, were all parts of cosmic imbalances which especially human beings were responsible for. They may or may not have caused them. In fact, they may be caused by anyone, but the consequences would definitely affect others, including themselves. That was the logic of the cosmic laws, they said. In response to it, what was important, in their arguments, was to learn and understand the causes and consequences and reflect on them. The pandemic was even a meaningful moment for both the interior self and the collective awareness and reflection.

\subsection{What Do Covid-19 and Nature Ask Us to Do?}

Based on the FKDS, especially those with topics on responses to Covid-19, representatives of kepercayaan groups shared ideas in common that it is to ask the questions: What do Covid-19 and nature ask us, the human beings, to do? Umbu Remi, ${ }^{24}$ the representative of Kepercayaan Marapu, East Nusa Tenggara, explained that according to Kepercayaan Marapu, a disease may be caused by 1) the self who transgressed existing cosmic rules, 2) external forces such as earthquakes, attacks by someone through spiritual forces and other things, as responses to misconduct by the self, 3 ) the venerated ancestor who punishes the people for their misconducts, not fulfilling their responsibilities, or ignoring their oaths, 4) other ancestors responding to an oath denial. The main oath of Marapu was to commit to the (indigenous religious) tradition centered on the cosmic balance required to fulfill the rights of all beings: human and nonhuman (the nature).

Covid-19 was perceived in that context. For Marapu people, Remi explained, Covid-19 was mainly caused by the disruption of the cosmic balance. Marapu people had expected something like Covid-19 to happen when witnessing a series of exploitation of natural resources, including their (indigenous) lands by corporations, legally guaranteed by the government.

For Marapu, such exploitation was against the cosmic laws. In their cosmology, the earth was the mother, and the sky was the father. If the mother was 
hurt or disturbed, the father would be angry and send punishment and admonition. They believed that Covid-19 was an admonition sent by the father to punish human beings for their extreme selfish desires. Covid-19, just like any bala (pandemic), came and asked us to restructure and rebalance the cosmos. For that reason, Remi stressed, the way to deal with Covid-19 was not to escape from it, but to face and follow the protocols, and more importantly to stop destroying the environment, stop deforestation, rebalance the cosmos as well as re-establish human-nature relationships.

Sukirman, ${ }^{25}$ the leader of Kepercayaan Kaharingan of South Kalimantan, similarly narrated that pandemic, bala in their term, was the "messenger" of the Supreme Being. Kaharingan people recognized more than 1400 bala, as many as humans' desires, thoughts, and behaviors. For them, bala such as Covid-19 appear as messengers to warn and punish human beings for their denials to obey the laws and ethics of the human-nature relationship. Sukirman pointed to the way people in his area and beyond irresponsibly, unlawfully and unethically exploited the lands. They destroyed the lands and forests for their own (human) pleasures, and ignored the rights of the land, forest, and other people. In addition to humans, Sukirman considered nature or non-human organisms to be valuable. He reflected an ecocentric way of thinking. ${ }^{26} \mathrm{He}$ added that anytime bala like Covid-19 come, humans are supposed to pause and look back. They are asked (by the bala) to look back on their previous behaviors and actions, assess them and review the laws and ethics of human-nature relationships. Humans ought not always to be bent on modern science and technology, diverting themselves from nature.

Sukriman shared that their people conducted a ritual of (warding off) bala as soon as they heard about Covid-19, reminded themselves of the messenger (of bala) conveying the message of humans' misconducts, and anticipated any possible impacts if the bala would eventually arrive at their community. If the bala Covid-19 eventually infected them, they would go to the forest. They would isolate themselves as a way of escaping from the bala and at the same time show their commitment to re-establish their human-forest (nature) relationship. For them, the forest was both life giver and protector, but functioned that way only if the people preserved and protected it. It was their indigenous way of dealing with any kind of bala, including Covid-19, Sukirman stated.

25 Sukirman, Kepercayaan/Agama Leluhur.

26 Taylor, Religion and Environmental Behaviour (part 2); Taylor, Dark green religion; Taylor/ Van Wieren/Zaleha, The Greening of Religion Hypothesis; Taylor/Chapron/Kopnina/ Orlikowska/Gray /Piccolo, The need for ecocentrism; Gladwin/Kennelly/Krause, Shifting Paradigms for Sustainable Development; Gray/Whyte/Curry, Ecocentrism. 
As opposed to Sukriman, followers of Kepercayaan Sapta Darma of East Java called the pandemic pageblug. Pageblug, according to their representative Naen Soeryono, ${ }^{27}$ always brings three-fold messages, which correspond to Fischer \& Four Arrows' questions. ${ }^{28}$ The first being pepeling, advice on and reminder of the existence of God. As pepeling, pageblug means that anything happening in this world, especially the pandemic Covid-19, is God's intentional will. It calls on humans to face the world, including Covid-19, with full surrender to God. For that reason, followers of Sapta Darma, as soon as they heard about Covid-19, performed sujud (an act of worshipping) for twelve nights. It was an act of invoking and surrendering to God, seeking for guidance to genuinely comprehend the pepeling, as well as strengthening community ties in facing the pandemic and impacts that came with it. The sujud was attended by a large number of community members in their place of worship before the government imposed its policy on lockdowns.

As second part of the message, pageblug represents the catastrophic threats humans have faced and experienced. According to Soeryono, pageblug must hence be perceived in relation to sasanti (ethical principles) of Sapta Dharmo: "ing ngendi bae, marang sapa bae, warga sapta darma kudu sumunar pindha baskara" (anywhere, wherever they are, and whoever they interact with, Sapta Darma members should shine like the sun). Based on that sasanti, each member should therefore carry the responsibilities of sharing and offering help to any infected individual, regardless of their identity background. In his presentation, Soeryono shared photographs of Sapta Darma members who organized a charity fundraising to donate to those in need and distribute disinfectants at different places of worship (not only their own) and other public buildings. Pageblug in this respect was a call for humanitarian care, Soeryono stressed. Soeryono implied, in other words, rather than being fearful, panicky, and isolating ourselves as lockdowns appeared to suggest, pageblug asks to engage even more in community services for solidarity.

The third meaning of pageblug, according to Soeryono, is about a real ongoing cosmic calamity that calls for cosmic harmony. Such an understanding is based on memayu hayu bawana (taking care of the nature) through the manifestation of walas asih (sincere love and grace), central to the teaching of Sapta Dharma. Pageblug comes to demonstrate that the human-nature relation is in trouble. Human beings have forgotten their roles and responsibilities in establishing cosmic harmony. For Sapta Dharma members, pageblug is a reminder of the principle of welas asih to nature. Soeryono elaborated that

27 Soeryono, Kepercayaan/Agama Leluhur.

28 Fischer/Four Arrows, Pandemic, Fearless, and an Indigenous Perspective. 
human and non-human beings share four elements: soil, water, weather, and fire/heat. Humans are therefore inseparable from non-human beings of the nature. They both share the same rights of well-being. Ignoring the rights of non-human beings of nature, humans would ruin themselves, and caring for their own well-being only would cause cosmic calamities. Similarly, Suprih Suhartono ${ }^{29}$ of Kepercayaan Kapribaden elucidated that humans consist of the outward (body) and the inward (spirit). The outward originates from four natural elements: soil, water, air, and fire, whereas the inward originates from God. Sooner or later, the four elements return to nature, and the spirit returns to God. Therefore, all human actions ought to be directed to the origins and goals: the vertical ones to God, and the horizontal ones to nature. Pageblug, Soeryono continued, is a reminder that humans have committed misconducts against nature out of selfishness, urging humans to re-establish sincere love and grace to nature as ways of loving themselves, and realize love in everyday life. Like Remi's and Sukirman's, Soeryono's indigenous ideas were central to ecocentric values. They all shared ideas of belonging, connecting, love of and loyalty to nature and its living systems. ${ }^{30}$

Engkus Ruswana ${ }^{31}$ of Kepercayaan Budi Daya also shared ecocentric values when explaining that the pandemic came to remind human beings who had alienated themselves from their inherent responsibilities, exploited nature without control, and disrespected their fellow humans. It was meant to (during the pandemic) raise self-awareness and reflection by looking back at the ancestors' (indigenous religious) values: sangkan paraning dumadi (the origin and purpose of being). Humans breathed, ate and drank from nature. Humans had forgotten whom they were dependent on (the nature). If nature was destroyed, humans would definitely be destroyed, too. Covid-19 reminded of nature being sick, carrying humans' interests beyond its capacity. To nature, Covid-19 was a medication. Nature was forced to do self-recovery from being ravaged by humans.

Echoing the previous arguments, but going further, Noor Sudiyati ${ }^{32}$ of Kepercayaan Hardo Pusoro of Yogyakarta narrated that Covid-19 was a being who had his/her own characteristics and rights. It was just like humans a guest of the earth. Being guests of the earth, both humans and Covid-19 came and went away. They came to the earth for purposes and went away according to the laws of the universe. Humans needed to understand Covid-19, and all other

\footnotetext{
29 Suhartono, Kepercayaan/Agama Leluhur.

30 Taylor, Religion and Environmental Behaviour (part two), p. 136.

31 Ruswana, Kepercayaan/Agama Leluhur.

32 Sudiyati, Kepercayaan/Agama Leluhur.
} 
existing cosmological beings, in order to live harmoniously. As a guest, Covid19 insisted on humans to adjust (for a new kind of life), the way that Covid-19 had to adjust to humans. However, it came as a disaster because all guests, humans, Covid-19 and other beings, had misunderstood each other. Humans had acted as 'viruses' to other beings, including to Covid-19, and in response, Covid-19 appeared to become dangerous to humans.

Similarly, for Kapribaden, according to their leader Suprih Suhartono, Covid19 brought about three lessons. First, it was a warning to human beings, especially to those who violated the truth and God's rules and disrespected their fellow humans. Second, it was a punishment for humans who were arrogant, justifying any means for their own desires, taking God's roles controlling the world, and forcing others to follow their steps. Third, it was a gift for humans. Covid-19 could lead humans to return to the nature of their existence and being (sangkan paraning dumadi). It reminded humans, like those of Kapribaden, to remain thanking God and close to God. Such an argument was also made by Kuswijoyo $^{33}$ of Kepercayaan Sumarah of Yogyakarta. He explained that Covid19 was a warning from God to human beings to always reflect on the self, their relation to their fellow humans, nature and God.

The above-mentioned narratives of Indonesian indigenous people in response to the Covid-19 pandemic were of course not unique. Like some other indigenous peoples in other parts of the world, ${ }^{34}$ those of Indonesia shared and promoted values and ethics of intersubjective relations through which they perceived relations between human and non-human organisms as being responsible, ethical and reciprocal..$^{35}$ Such indigenous knowledge of intersubjective relations was clearly the foundation for their responses to Covid-19 that it came to remind and ask human beings to re-establish harmonious humannature relations. ${ }^{36}$

\subsection{Ecocentric Sacrificial Ritual}

It was common among indigenous people of Indonesia that rituals of (animal) sacrifice were the first thing to do in dealing with crisis. Such rituals were commonly known as tolak bala (Ind., warding off crisis) such as the pandemic. This section presents other four indigenous communities of Indonesia whose representatives shared information on ritual practices in a radio talk show

33 Kuswijoyo, Kepercayaan/Agama Leluhur.

34 La Follette/Maser, Sustainability and the Rights of Nature; Berkes, Sacred Ecology; Gadgil/ Fikret/Folke, Indigenous Knowledge for Biodiversity.

35 Maarif, Indigenous Religion Paradigm; Curry, Ecological Ethics; Kimmerer, Braiding Sweetgrass; Washington, A Sense of Wonder.

36 Taylor/Chapron/Kopnina/Orlikowska/Gray/Piccolo, The Need for Ecocentrism. 
by AmAn: Saga people of Nusa Tenggara Timur (NTT); Dayak Kanayan, the indigenous community of Pahuman, West Kalimantan; the Mentewe of South Kalimantan; and Simbuang of Tana Toraja, South Sulawesi. ${ }^{37}$

Traditionally speaking, a pandemic was nothing alien to Saga people. Pilipus Kami of the Saga community informed the audience that Saga people performed the ritual of Tuju (an invisible being who usually attacked and killed people) and of Joka Ule (another being who looked like a small snake usually destroying gardens and plants and killing animals) as responses to Covid-19. Covid-19 was perceived as either Tuju or Joka Ule. The rituals were to ward off threats and impacts brought by the Covid-19 pandemic - dangerous to people. They involved a pig sacrifice which was understood as being demanded by Covid-19. After being chanted by specialists, the sacrificed pig was brought to a (sacred) place, and then a contract between the people, the animal and Covid19 was made. Covid-19, being offered the sacrificed pig, was thus expected not to enter the village, and not to kill the people, plants or other animals.

Tatang of Dayak Kanayan shared similar information. On 20 March 2020, two weeks after the government officially announced the national emergency due to Covid-19, he and his people performed the ritual of Muang Sampar (literally means warding off contagious diseases). Covid-19 was perceived as sampar (contagious disease). The ritual was led by a specialist called penengahan. It involved chickens, eggs and rice amongst others as gifts to the sampar (Covid-19). Similar to Saga people's perspective, the gifts were part of the contract made between the people and Covid-19. The contract was not meant to hurt Covid-19, but to invoke it to go back to where it came from. The Creator, in the ritual, was also invited to help Covid-19 navigate its way home.

Satra of Mentewe, South Kalimantan in turn explained that as soon as they heard about Covid-19, the community leaders and ritual specialists (belian) gathered and decided to perform a ritual of Menyanggar, which literally means (re)marking the limit, in the end of March 2020. Menyanggar ritual was to reestablish the limit of rights and responsibilities belonging to human and nonhuman beings. It was for every being to realize the danger of intervening in the rights of others and the necessity to carry their own responsibilities. For the ritual, they sacrificed one pig, seven chickens, and forty-one colored kinds of traditional cakes. Those were gifts to ancestors invited to participate in dealing with Covid-19. Based on their previous experiences with different kinds of pandemic, in Mentewe's understanding the ritual was an effective contract with Covid-19 that prevented it from attacking them as long as they were committed to re-establishing the limits rather than transgressing them, including health 
protocols for the Covid-19 like social distancing. After performing the ritual, they continued with their everyday community activities like farming and fishing instead of working from home according to the lockdown measures that had been enforced in many areas during the early days of the pandemic. However, outsiders were monitored when entering their territory.

Ambe Manda of Tana Toraja, South Sulawesi, with the help of an interpreter, explained that his people dealt with Covid-19 by performing the ritual of Makrinding Bamba, which literally means building a wall (makrinding) to block the gate ( $b a m b a)$. The ritual was to block the path of any disease or destructive force that wanted to enter the villages. The ritual was conducted at midnight, the best time for such a ritual as it requires a quiet atmosphere. Anyone was allowed to participate, from children to the elderly, male and female, but the number of participants had to be even. The ritual of Makrinding Bamba also involved offerings consisting of sacrificed chickens, sticky rice, betel leaves and the like.

For those indigenous people, the rituals were conducted for at least two purposes. First, the ritual was to prevent Covid-19 from entering the village. Cosmologically, Covid-19 was understood to already be in a contract with the people and other cosmic beings and that the rights and responsibilities were re-established for all beings involved. As long as the people adhered to the contract through their rituals (carrying their responsibilities to respect and protect the rights of other beings whereby other beings carry their responsibilities to protect and respect the rights of the people), they should no longer be afraid of and panic about Covid-19 and all the dangers it may bring. Second, sociologically the ritual was a medium of informing the people about Covid19 and all issues related to it, including (outsiders' modern) medical ways of treating it. The four representatives of the indigenous peoples informed that their people were well-informed of the Covid-19 protocols. They were neither involved in debates, nor engaged in any conspiracy theories. They followed the protocols as instructed by the government and medics, but their community activities remained normal, meaning that they continued doing their jobs like farming, fishing, etc. For Saga people, Kami implied, Covid-19 was admitted to be real, bringing deathful dangers, but should not cause people to panic. Tatang of Dayak Kanayan in turn explained that in order to be effective, the ritual of Muang Sampar had taboos to comply with. After the ritual, no one was allowed to leave the house for a certain number of days. Staying at home for at least three days was obligatory. Social gathering, let alone creating and getting involved in social conflict, was not allowed and forcefully monitored. In addition to that, community members were encouraged to consume traditional herbs they had gathered in their surroundings. 
Some may deem those rituals to be opposing ecocentrism (deep green) or even biocentrism and animal liberation (mid-green environmental ethics), ${ }^{38}$ because they involve the killing of animals. Those rituals described above were conducted for the benefit of humans only - other living beings had no value. Rene Girard ${ }^{39}$ would argue that the violent aspects of sacrificing rituals are for people to channel their violent energies towards animals. Animals had been chosen because they are thought to be less likely to take revenge. Walter Burkert ${ }^{40}$ would similarly argue that the killing of fellow living beings had been ritualized; hence, people would not feel as if committing any crime. They decriminalized the killing.

It is worth noting that based on the ways the four indigenous peoples lived with and treated those sacrificed, those animals were significant others in the lives of those indigenous people. They were among the closest and thus most significant others in their cosmology and everyday life. Those animals were not only offerings, but also had ecological roles. For the Marapu people of East Nusa Tenggara, pigs and chickens were actually the most truthful "messengers" of life guidance. If they encountered new problems without any precedence, in order to solve them, they consulted the animals by reading the animals' hearts. To do so, the Marapu still had to slaughter (sacrifice) the animals; however, slaughtering them was perceived as a collective sacrifice for ecological solidarity for the well-being of humans and non-humans, including the fellows of the sacrificed chickens and pigs. For the Marapu, it was not only the pigs or the chickens that sacrificed themselves, but also the people who raised them and took care of them. They sacrificed by sincerely letting go of the sacrifice with whom they had built up strong emotional bonding as relatives.

Mark Woodward suggested observing the system of cosmology within which those rituals were situated (2000). Rituals of the above-mentioned four indigenous communities are comparable to those of the Ammatoans, the indigenous people of South Sulawesi, Indonesia. ${ }^{41}$ They were to re-contextualize cosmological communion of all involved beings: humans and non-humans. Those indigenous peoples shared a cosmology according to which the cosmos was occupied by different persons/subjects: human and non-human beings ${ }^{42}$ recognizing each other through a series of encounters through which they comprehended personhood (capacities, values) of their own and others'.

\footnotetext{
38 Fennell, Ecotourism, Animals and Ecocentrism.

39 Girard, Violence and the Sacred.

40 Burkert, Homo Necans.

41 Maarif, Dimensions of Religious Practice; Maarif, Being a Muslim in Animistic Ways; Maarif, Ammatoan Indigenous Religion.

42 Maarif, Indigenous Religion Paradigm.
} 
Such cosmology was the basis for their relational systems facilitating interpersonal relationships. In these systems, the animals' purpose was understood as carrying responsibilities for the wellbeing of others - their responsibilities being in relation to their rights and to the rights and responsibilities of others, including humans. Those sacrificed pigs, in such cosmological systems, were not only for responses to the Covid-19, but also for the well-being of their fellow (living) pigs. Human beings were responsible to make sure that the inwards (spirits) of sacrificed pigs and chickens would be in the right place of the next life, in unity and communion with (human and animal) ancestors, whereas their outwards (fleshes) would be in unity with the human fleshes (through consumption). Human beings, furthermore, were to raise and make sure that the living pigs were healthy and well, and the (living) pigs in turn would play their roles in accordance to their personhood, capacities and values.

Those rituals of sacrifice may therefore be understood as ecocentric performances. They were to respond to Covid-19 as endangering the life of humans and all other beings. Based on their ecocentric ways of knowing and being, indigenous people understood that a disease or crisis was existentially collective. As narrated by a representative of indigenous people in the previous section, Covid-19 was caused by human misconducts against humanity, the nature, the forest, the land to fulfil their selfishly uncontrolled desires, and those misconducts had ruined human-nature relations, and thus inflicted suffering and even deaths. Those rituals were also meant to re-establish humannature relations, at least for their own people.

\subsection{Re-Establishing Ecological Relations}

According to Noor Sudiyati of Hardo Pusoro, ${ }^{43}$ the earth had been seriously infected by the virus of humans' interests, and so needed an "antivirus" for its well-being. For such a purpose, Covid-19 came as an "antivirus" to eradicate various viruses that had destroyed the earth. It came to call for revolutionary awareness for re-managing the earth, in fact, the universe (ngugemi pranataaning jagad). Noor Sudiyati and other followers of indigenous religions of Indonesia shared what Taylor ${ }^{44}$ noted that outside "world religions", there were ecocentric religions whose teachings were central to conserving nature's biodiversity. ${ }^{45}$ Along the line, Engkus Ruswana of Budi Daya ${ }^{46}$ explained in his

43 Sudiyati, Kepercayaan/Agama Leluhur.

44 Taylor, Religion and Environmental Behaviour (part 1).

45 Taylor, Religion and Environmental Behaviour (part 1), p. 71; Taylor, Religion and Environmental Behaviour (part 2), p. 136.

46 Ruswana, Kepercayaan/Agama Leluhur. 
presentation that human beings consisted of four elements: 1) air, making up the breath of human beings, 2) water, making up their blood, 3) soil, making up the human flesh, and 4) the fire/heat, making up emotions of humans. Those elements, also making up animals, plants and any other living thing, came from nature. Human beings, animals, plants and others shared the same elements coming from nature. Humans and non-humans were therefore inseparably interrelated. Ruswana emphasized that protecting ourselves actually meant protecting nature, and destroying nature basically meant destroying the self.

Ruswana furthermore explained that humans and nature are mutually responsible and interdependent. Human beings, in his perspective, must carry ethical responsibilities for the well-being of themselves as well as of nonhuman beings. ${ }^{47}$ Human beings have inherent roles in preserving nature, in response to nature's role in carrying humans' existences. He referred to the Budi Daya principles of daily life which were centered on ngertakeun bumi lamba and mamayu hayuning bawono (taking care of earth's prosperity) for human-nature relations. In more detail, Ruswana explored that, based on Budi Daya teaching, the self is the servant of God, the (human) inward is the servant of the nature, and the (human) outward is a community member, and/or a citizen of the state who is responsible for engaging in gotong royong (social cooperation) for collective interests. Based on such an understanding, Budi Daya followers should live the life of being silih asih, silih asuh, silih asah (loving, caring, and enriching) to humans and nature alike by carrying out ways of cageur (being physically healthy, taking care of the body), bageur (being ethical and moral, taking care of behaviors), bener and pinter (thinking smartly and rightly, taking care of the mind), jujur (being honest, taking care of interrelation); salamet (being happy and peaceful). To carry out those is to live in simplicity by fulfilling the basic needs as reflected in the saying of Budi Daya: dahar sakadar tamba lapar (eating only to cure hunger); nginum sakadar tamba hanang (drinking only to cure thirst), and sare sakadar tamba tunduh (sleeping only to cure sleepiness).

It was also stated in the Budi Daya pikukuh (guidance) and taboo that gunung teu meunang digempur, leuweung teu meunang diruksak (the mountain may not be mined and the forest may not be destroyed). This passage emphasized the necessity to protect or govern human-nature relations. In practice, the Budi Daya community managed their forest/land by dividing it into exploitable and the protected forests/land. The latter was for humans to protect, and the former was the gift of the protected nature to humans. To govern this relation effectively, being greedy was taboo for it was the source 
of destructing human-nature relations. The pikukuh and taboo were ritualistically practiced. To live their lives, Budi Daya followers were dependent on the gift of the nature. They explored the traditionally designated land, but any time they were in contact with the land/nature, they communicated with or asked for permission (mipit amit, ngala bebeja) in advance from God, nature and all animals as well as any living beings dwelling in nature. Mipit amit, ngala bebeja was a daily practice of ethical relationship between human and nature. They both respected one another. Budi Daya followers were even expected to do mipit amit, ngala bebeja soon they contacted the nature, including when, for instance, they went outside their houses.

In addition, the Budi Daya community had several rituals of recontextualizing human-nature relations. Ruswana shared three of them as examples. The first was seren taun (thankfulness). This ritual was performed annually to express their thankfulness to God and nature for what nature including animals and plants have contributed to people's lives. The second was muangtarima, the ritual of gift exchange between humans and nature. Whenever Budi Daya followers succeeded in their work, they shared some of their gains with their fellow humans and nature through offering. Ruswana explained that what we give (through working with nature) is what we take (like food, the gift of nature), and what we take (the gift) is what we give (planting, taking care of, and so protecting the nature), and the ritual of offering was to renew the (contract of) reciprocity, fundamental in human-nature relations. ${ }^{48}$ The third is ruwat (ritual of purifying or warding off diseases). This ritual was conducted to purify the village, wells or water springs from any kind of visible and invisible diseases, including pandemics such as Covid-19, explained Ruswana. Those rituals and everyday practices were sources of Budi Daya followers' perception of human-nature relationships: responsible, ethi$\mathrm{cal}$, reciprocal. They perceived and experienced the existence of nature and all its ecosystems as living beings, persons and subjects. Taylor would argue that Budi Daya followers appreciated the beauties and values of intact ecosystems, realizing that all organisms had their own forms of intelligence and thus respecting them. ${ }^{49}$

48 Maarif, Indigenous Religion Paradigm.

49 Taylor, Religion and Environmental Behaviour, p. 136. 
The pandemic, despite the greatly complicated challenges it brought, had somehow empowered indigenous peoples to engage in public discourses. In the early days of the pandemic, a group of individuals concerned with issues of minority groups, such as indigenous peoples, gathered in order to ponder ways of dealing with the chaos in the pandemic's wake. They agreed to acknowledge that the pandemic had shaken all established orders, challenged political, economic, socio-cultural and religious authorities and questioned scientific, religious and all other kinds of truths, but at the same time opened new spaces and opportunities for all, including those whose voices had not been reckoned before the pandemic. New spaces and opportunities did not mean availability of resources ready to access, but rather to compete and to contest for any ideals. The group also agreed that it was the internet that facilitated new spaces and opportunities. The internet was not new of course, but only certain categories of groups had enjoyed access before the pandemic. It had been a kind of luxury. When, due to lockdowns and social distancing, the internet became the most reliable tool of communications during the pandemic, it came to be seen not only as a mere tool to utilize, but as an opportunity to provide new spaces of advancing advocacies for indigenous people. The group of initiators realized that it would not be easy, understanding that the internet was expensive for indigenous peoples, but that was what an opportunity was about. Following that idea up, the group offered the idea of weekly seminars to representatives of indigenous religions.

It was the weekly seminars called Forum Kamisan Daring by the initiative working together with these representatives that aimed at making it easier for religious communities of the archipelago to share their issues and concerns as well as articulate their indigenous religions and wisdoms. The weekly seminars were even followed up by the second international conference on indigenous religions in December 2020, which also involved international scholars. As observed, many other online seminars were also organized for various issues of indigenous peoples by several civil society organizations, including the state's departments. Forum Kamisan Daring, as said before, was set up for the unique purpose of providing an opportunity for representatives of indigenous religions to be main speakers, but involving significant personalities of public life.

Being main speakers in public was hitherto unthinkable for many members of indigenous peoples. One of the speakers of the forum expressed, "I never thought I would have a chance to share what I believe and think. I never thought that people would ever listen to me. I did not expect that people would appreciate and appraise our beliefs, our wisdoms, and our ways 
of life. ${ }^{50} \mathrm{He}$ was truly impressed that participants of the online forum shared positive responses to ideas and religious-cultural practices of indigenous peoples. It made a deep impression on him because it was not until he became a speaker in the forum that he had been subdued into believing that his indigenous religion was not acceptable to the public. He had been learning for a very long time that people associated his indigenous religion with a variety of negative stigmas such as being irrational, primitive, magic, animistic, pagan, infidel, irreligious and even satanic.

Their indigenous eco-centric ideas in dealing with the pandemic were appreciated. Responses from the public in those weekly seminars appraised the ideas as practical. They were everyday practices. Indigenous ecology as shared by those representatives was a set of ideas and practices of human-nature relationship. Those representatives, together with other participants of the forum called for the re-establishment of inter-subjective human-nature relationship not only in dealing with the pandemic, but also in advancing the future new normal of responsible, ethical and reciprocal human-nature relationship.

\section{Acknowledgments}

This paper was partially supported by DIKTI and RISPRO LPDP. This research was part of "Agama dan Covid-19: Studi Komparatif Inovasi Keagamaan dan Solidaritas Sosial di Indonesia", supported by the Indonesian Ministry of Research and Technology, and of "Ekowisata Untuk Pelestarian Ekologi Adat dan Pengembangan Ekonomi Kreatif Berbasis Komunitas di Masyarakat Adat Ammatoa Kajang, Sulawesi Selatan", supported by LPDP, the Indonesian Ministry of Finance.

\section{Biography}

Samsul Maarif teaches Indigenous Religions at the Center for Religious and Cross-cultural Studies (CRCS), an MA program in Religious Studies at the Graduate School of Universitas Gadjah Mada. He has been working closely with indigenous people, civil society organizations as well as government officials of Indonesia to engage in intersectoral collaboration for "centering the margins", like indigenous people. His research interests include inclusive citizenship, interreligious relations, religious ecology, and community development.

50 Sukirman (in a personal communication on 21.05.2021). 


\section{Bibliography}

Aliansi Masyarakat Adat Nusantara: Homepage, https://www.aman.or.id/ (date of last access: 20.09.2021).

Bell, Catherine: Paradigms behind (and before) the Modern Concept of Religion, in: History and Theory 45 (4/2006), pp. 27-46.

Berkes, Fikret: Sacred Ecology (Second Edition). New York, NY/London: Routledge 2008.

Buhrmann, M. Vera: Living in Two Worlds: Communication between a White Healer and Her Black Counterparts. Cape Town, South Africa: Human \& Rosseau 1986.

Burkert, Walter: Homo Necans: The Anthropology of Ancient Greek Sacrificial Ritual and Myth. Berkeley, CA: University of California Press 1983.

Cox, James L.: From Primitive to Indigenous: The Academic Study of Indigenous Religions. Burlington, VT: Ashgate Publishing Ltd 2007.

Curry, Patrick: Ecological Ethics: An Introduction. Cambridge: Polity Press 2011.

Du Toit, Brian M.: Modern Folk Medicine in South Africa, in: South African Journal of Ethnology 21 (4/1998), pp. 145-152.

Dubuisson, Daniel: The Western Construction of Religion: Myths, Knowledge, and Ideology. Baltimore, MD: Johns Hopkins University Press 2003.

Fennell, Davida: Ecotourism, Animals and Ecocentrism: A Re-examination of the Billfish Debate, in: Tourism Recreation Research 38 (2/2013), pp. 189-202.

Fisher, R. Michael and Four Arrows: Pandemic, Fearless, and an Indigenous Perspective: A dialogue, in: International Journal of Fear Studies 2 (2/2020), pp. 75-80.

Gadgil, Madhav/Fikret, Berkes/Folke, Carl: Indigenous Knowledge for Biodiversity Conservation, in: Ambio 22 (1993), pp. 151-156.

Girard, Rene: Violence and the Sacred. Baltimore, MD: Johns Hopkins University Press 1977.

Gladwin, Thomas N./Kennelly, James J./Krause, Tara-Shelomith.: Shifting Paradigms for Sustainable Development: Implications for Management Theory and Research, in: The Academy of Management Review 20 (4/1995), pp. 874-907.

Gray, Joe/Whyte, Ian/Curry, Patrick: Ecocentrism: What it means and what it implies, in: The Ecological Citizen 1 (2/2018), p. 13 o et seq.

ICIR (Intersectoral Collaboration for Indigenous Religions): Homepage, https://icir .or.id/ (date of last access: 20.09.2021).

Indigenous Services Canada: Addressing Urgent Needs in Indigenous Communities Related to COVID-19, 2020, https://www.canada.ca/en/indigenous-services-canada/ news/2020/03/addressing-urgent-needs-in-indigenous-communities-related-to -covid-19.html (date of last access: 10.06.2020).

Ismail, Faisal.: Pancasila as the Sole Basis for all Political Parties and for all Mass Organizations: An Account of Muslims' Responses. in: Studia Islamika 3 (4/2014), pp. 1-92. 
Jehanu, Valerianus B.: Kepercayaan dan Pandemi: Antologi Esai Penghayat Kepercayaan Menghadapi Covid-19. Yogyakarta: Yayasan Satunama 2020.

Kimmerer, Robin W.: Braiding Sweetgrass: Indigenous Wisdom, Scientific Knowledge and the Teachings of Plants. Minneapolis, MN: Milkweed Editions 2013.

Kuswijoyo: Kepercayaan/Agama Leluhur Menyikapi Covid-19, in: ICIR Rumah Bersama: Forum Kamisan Daring Seri \#, 07.05.2020.

La Follette/Maser, Cameron/Maser, Chris (eds.): Sustainability and the Rights of Nature in Practice. Boca Raton, FL: CRC Press 2019.

Longmore, L.: Medicine, Magic and Witchcraft among Urban Africans on the Witwatersrand, in: Central African Journal of Medicine 4 (6/1958), pp. 242-249.

Maarif, Samsul/Mubarok, Husni/Sahroni, Laela Fitriani/Roessusita, Dyah: Merangkul Penghayat Kepercayaan melalui Inklusi Sosial: Belajar dari Pengalaman Pendampingan. Kerja sama CRCS, Pusad Paramadina, dan Yayasan Satunama. Yogyakarta: CRCS UGM 2019.

Maarif, Samsul: Being a Muslim in Animistic Ways, in: Al-Jamiah: Journal of Islamic Studies 52 (1/2014), pp. 149-174.

Maarif, Samsul: Dimensions of Religious Practice: The Ammatoans of Sulawesi, Indonesia. Dissertation. Arizona State University 2012.

Maarif, Samsul: Indigenous Religion Paradigm: Re-interpreting Religious Practices of Indigenous People, in: 哲学 • 思想論集 = Studies In Philosophy 44 (2019), pp. 56-103.

Maarif, Samsul: Meninjau Ulang Definisi Agama, Agama Dunia, dan Agama Leluhu. In: I. Ali-Fauzi/Z.A. Bagir/I. Rafsadi (eds.): Kebebasan, Toleransi dan Terorisme: Riset dan Kebijakan Agama di Indonesia. Jakarta: Pusat Studi Agama dan Demokrasi, Yayasan Paramadina 2017, pp. 13-48.

Maarif, Samsul: Pasang Surut Rekognisi Agama Leluhur di Indonesia. Yogyakarta: CRCS UGM 2017.

Maarif, Samul: Ammatoan Indigenous Religion and Forest Conservation, in: Worldviews: Global Religions, Culture, and Ecology 19 (2/2015), pp. 144-16o.

Majelis Luhur Kepercayaan: Peraturan \& Perundangan, https://www.mlki.or.id/ (date of last access: 20.09.2021).

Masuzawa, Tomoko: The Invention of World Religions: Or, How European Universalism Was Preserved in the Language of Pluralism. Chicago, IL: University of Chicago Press 2005.

Ngubane, H.: Body and Mind in Zulu Medicine: An Ethnography of Health and Disease in Nyuswa-Zulu Thought and Practice. London: Academic Press 1977.

Owen, Suzanne: The World Religions paradigm Time for a change, in: Arts and Humanities in Higher Education 10 (3/2011), pp. 253-268.

Picard, Michel/Madinier, Rémy: Politics of Religion in Indonesia: The Syncretism, Orthodoxy, and Religious Contention in Java and Bali. London/New York, NY: Taylor \& Francis 2011 . 
Refworld: Constitution of the Republic of Indonesia, 1945 (last amended in 2002), https:// www.refworld.org/docid/46af43fiz.html (date of last access: 10.09.2021).

Remi, Umbu: Kepercayaan/Agama Leluhur Menyikapi Covid-19, in: ICIR Rumah Bersama: Forum Kamisan Daring Seri \#3, 21.05.2020, https://www.facebook.com/ icrs.yogya.10/videos/141411020799785 (date of last access: 20.09.2021).

RGA Online Radio: Beranda, https://radio.aman.or.id (date of last access: 20.09.2021).

Robinson, Geoffrey B.: The Killing Season: A History of the Indonesian Massacres, 1965-66. Princeton, NJ: Princeton University Press 2018. https://doi.org/10.1515/ 9781400888863 .

Ruswana, Engkus: Kepercayaan/Agama Leluhur Menyikapi Covid-19, in: ICIR Rumah Bersama: Forum Kamisan Daring Seri \#2, 14.05.2020, https://www.youtube.com/ watch?v=j53bRPc5oC8 (date of last access: 20.09.2021).

Sepkowitz, Kent: The Risk to Native American nations from Covid-19, https://edition.cnn .com/2020/04/o7/opinions/native-american-nations-risk-from-covid-19-sepkowitz/ index.html (date of last access: 10.06.2O20).

Smith, Jonathan Z.: Map is not Territory: Studies in the History of Religions. Chicago, IL: University of Chicago Press 1978.

Smith, Jonathan Z.: Religion, Religions, Religious. In: M.C. Taylor (ed.): Critical Terms for Religious Studies. Chicago, IL: University of Chicago Press 1998, pp. 269-284.

Smith, Wilfred C.: The Meaning and End of Religion. Minneapolis, MN: Fortress Press 1991.

Soeryono, Naen: Kepercayaan/Agama Leluhur Menyikapi Covid-19, in: ICIR Rumah Bersama: Forum Kamisan Daring Seri \#1, 07.05.2020, https://www.youtube.com/ watch?v=f9AUKUJd_-4\&t=468s (date of last access: 20.09 .2021 ).

Sudiyati, Noor: Kepercayaan/Agama Leluhur Menyikapi Covid-19, in: ICIR Rumah Bersama: Forum Kamisan Daring Seri \#1, 07.05.2020, https://www.youtube.com/ watch?v=f9AUKUJd_-4\&t=468s (date of last access: 20.09.2021).

Suhartono, Suprih: Kepercayaan/Agama Leluhur Menyikapi Covid-19, in: ICIR Rumah Bersama: Forum Kamisan Daring Seri \#2, 14.05.2020, https://www.youtube.com/ watch?v=j53bRPc5oC8 (date of last access: 20.09.2021).

Sukirman: Kepercayaan/Agama Leluhur Menyikapi Covid-19, in: ICIR Rumah Bersama: Forum Kamisan Daring Seri \#3, 21.05.2020, https://www.facebook.com/icrs.yogya.10/ videos/141411020799785 (date of last access: 20.09.2O21).

Taylor, Bron R./Van Wieren, G./Zaleha, B.: The Greening of Religion Hypothesis (part two): Assessing the Data from Lynn White, Jr, to Pope Francis, in: Journal for the Study of Religion, Nature and Culture 10 (3/2016), pp. 306-378.

Taylor, Bron R.: Dark green religion: Nature spirituality and the planetary future. Berkeley, CA: University of California Press 2010.

Taylor, Bron R.: Religion and Environmental Behaviour (part one): World religions and the Fate of the Earth, in: The Ecological Citizen 3 (2019), pp. 71-76. 
Taylor, Bron R.: Religion and Environmental Behaviour (part two): Dark-green Nature Spiritualities and the Fate of the Earth, in: The Ecological Citizen 3 (2020), pp. 135-40. Taylor, Bron/Chapron, Guillaume/Kopnina, Helen/Orlikowska, Ewa/Gray, Joe/Piccolo, John J.: The Need for Ecocentrism in Biodiversity Conservation, in: Conservation Biology 34 (5/2020), pp. 1089-1096.

Tuhri, Mufdil: Adat, Land, and Religion: The Politics of Indigenous Religions in Indonesia. MA thesis. Universitas Gadjah Mada 2019.

Vieira, C.M./Franco, O.H./Restrepo, C.G./Abel, T.: COVID-19: The Forgotten Priorities of the Pandemic, in: Maturitas 136 (2020), pp. 38-41.

Washington, Haydn: A Sense of Wonder towards Nature: Healing the Planet through Belonging. London: Routledge 2019.

Widodo, Kasmito: Dampak Hilangnya Wilayah Adat dalam Kebijakan Satu Peta, https://www.youtube.com/watch?v=mky5nVKwZUI\&t=770s, 1.09.05-1.24.45 (date of last access: 17.02.2O21).

Woodward, Mark R.: Gifts for the Sky People: Animal Sacrifice, Head Hunting and Power among the Naga of Burma and Assam. In: G. Harvey (ed.): Indigenous Religions: A Companion. London/New York, NY: Casell 200o, pp. 219-229. 